\title{
Role of data mining in establishing strategic policies for the efficient management of healthcare system - a case study from Washington DC area using retrospective discharge data
}

\author{
Harleen Kaur ${ }^{* *}$, Ritu Chauhan², Zafar Ahmed ${ }^{3}$ \\ From The 6th International Casemix Conference 2012 (6ICMC2012) \\ Kuala Lumpur, Malaysia. 6-7 June 2012
}

\section{Background}

Many physicians are perplexed with an acute increase in the rate of pregnancies and live birth, and a decrease rate of abortions among the women in the Washington DC area. Healthcare managers are analyzing the admission and discharge data to understand this trend. There are many factors such as marital status, age, income, health problems during pregnancy, insurance coverage and other treatment expenses, existence of psychological and emotional problems, patients experience while stay at hospital, and most importantly the increasing cost of abortion that can lead to this sudden increase in rate of live birth and subsequent decrease in the abortion rate in Washington DC area.

\section{Objective}

The main objective of this study is to study the factors that lead to this increase in the rate of pregnancies and live birth, and decrease in the rate of abortion in the Washington DC area.

\section{Methodology}

A qualitative approach is used to evaluate and determine the factors that have lead to this increased rate of pregnancies and live child births in Washington, DC area. The Data mining, clustering and statistical techniques were used to evaluate the Casemix datasets to understand

\footnotetext{
* Correspondence: harleen.k@unu.edu

${ }^{1}$ United Nations University International Institute of Global Health (UNU-\|GH), Kuala Lumpur, Malaysia
}

Full list of author information is available at the end of the article the causes increased rate of pregnancies, live birth and reduce rate of abortions in Washington, DC area. Eight hospitals in Washington DC area were randomly selected and included in this study. The Casemix data set of the patient giving live birth at these eight hospitals were abstracted and studied from January to December 1992. The associated patterns leading to the increased rate of live birth and decrease rate of abortions are discovered for further analysis with $\mathrm{K}$ means clustering and other statistical techniques.

\section{Results}

The cost of abortion is the main factor, among the positive factors, that has lead to an increase rate of live births among the cases studied. The unmarried women who cannot afford the cost of abortion were ranked among the highest to continue with the pregnancy whereas the rate of live birth was lowest among the married women's.

\section{Conclusion}

This type of information will provide the basis for the proper strategic planning and can help establish policies to provide assistance to the unmarried women's for abortions or a different policy's to remove the cost of burden for abortion. The study may help to develop policies that can lead to a decrease in the rate of live births due to increase in cost of abortion.

\footnotetext{
Author details

'United Nations University International Institute of Global Health (UNU-IIGH), Kuala Lumpur, Malaysia. ${ }^{2}$ Hamdard University, New Delhi, India.
} 
${ }^{3}$ International Case Mix and Clinical Coding Centre, UKM Medical Centre, Faculty of Medicine, University Kebangsaan Malaysia, Kuala Lumpur, Malaysia.

Published: 21 November 2012

doi:10.1186/1472-6963-12-S1-P12

Cite this article as: Kaur et al:: Role of data mining in establishing

strategic policies for the efficient management of healthcare system - a case study from Washington DC area using retrospective discharge data. BMC Health Services Research 2012 12(Suppl 1):P12.

Submit your next manuscript to BioMed Central and take full advantage of:

- Convenient online submission

- Thorough peer review

- No space constraints or color figure charges

- Immediate publication on acceptance

- Inclusion in PubMed, CAS, Scopus and Google Scholar

- Research which is freely available for redistribution

Submit your manuscript at www.biomedcentral.com/submit
() Biomed Central 